\title{
The Infiltration of Ideological and Moral Education in College Physical Education
}

\author{
Zhang Yaoliang \\ Zhuhai College of Jilin University, Zhuhai, China \\ 279399748@qq.com
}

Keywords: College Students, Ideological and Moral Education, Physical Education

\begin{abstract}
Ideological and moral education in higher education is an important way for students to build spiritual civilization. As an important part of college education, physical education is of great significance. The mutual penetration between the two is not only the strong will of college students exercise, but also the creation of excellent psychological quality, so that students can have a great degree of Ideological and moral sublimation. For college students, physical education is not only the basic skills of sports, technology and related knowledge, the spirit of the world is also very important [1]. Therefore, physical education teachers in the teaching process, not only to teach the basic knowledge of sports, but also the ideological and moral education into the daily physical education. At the same time, the importance of Ideological and moral education in physical education should be studied, in order to improve the quality of College students.
\end{abstract}

\section{The importance of Ideological and Moral education}

As one of the compulsory courses in Colleges and universities, physical education plays an important role. It can not only make the students' physical fitness, but also contribute to the prosperity of the country and the independence of the nation, according to Mao Zedong's thought of "empowering the country with sports"[2]. In the process of physical education, physical education teachers should observe the quality of students' will, personality, hobbies and ideological behavior.

College students, as the hope of the nation, are closely related to the overall development of the country and the future of the country. Therefore, college teachers should help them to discriminate between right and wrong and help them to establish the values, outlook on life and world outlook of socialism with Chinese characteristics. In the process of physical education, it is necessary not only to exercise its strong body, but also to lead and guide the spiritual world. Therefore, ideological and moral education is particularly important.

In view of the present social situation, college education is an important stage for people to cultivate and improve their ideology, morality and will. In the process of physical education in Colleges and universities, students can expand their knowledge, improve their ability, and change their thoughts and feelings. Physical education teachers' Ideological and moral education of students on the formation of students' character and will play a positive role to a certain extent, contribute to the formation of their world outlook[3].Nowadays, the accelerated development of society has brought new demands and challenges to the ideological and moral education. 


\section{The Main Content of College Students' Ideological and Moral Education}

In view of college students' ideological and moral education, it is very important to grasp the core of education, and college teachers should shape the values of students on the basis of faith and ideal. Carrying forward the national spirit with patriotism as the core of college students, carrying out ideological education on the basis of ethics, and strengthening the quality education of students. As a result, students can have a comprehensive and comprehensive development. The ultimate goal of education is to make people more valuable, meaningful, and make life more fulfilling. The ideological level of education is very important, the current combination of mainstream education and physical education for college students' ideological and moral cultivation of the foundation[4].Colorful physical education has become an important way to improve the ideological education. The development of the students is the essential requirement of education, and the students can develop in the relaxed and enjoyable teaching activities. Through the way of outdoor teaching, physical education has carried on the thorough excavation to the student's nature. Open Physical Education in the development of students' ability, but also to the formation of students' values, feelings and attitudes to promote. The enthusiasm and interest of the students can also be awakened by the success, with the desire for learning, students can actively develop the main spirit.

In the process of physical education teaching for college students, students' attitude, emotion and thought will soon be exposed. In view of these problems, teachers can guide students, teach students to treat with non, long and short, and defeat the correct attitude, students face the difficulties of courage, achieve psychological barriers across shaping students' self-confidence and self-esteem attitude[5].This is not only conducive to emotional stability, but also enhance the students' ability of psychological adjustment and control of self-behavior, shape, firm and indomitable spirit never yield in spite of reverses.

In the course of physical education for college students, all kinds of physical activities are carried out in the form of individual or group of students. In the process of activities, there is a more direct contact between individuals, groups, individuals and individuals. In this process, the interaction between the middle school students has formed a social model. The imitation of education mode on the social environment, help students to his self any further understanding of students' ability to adapt to the social reality also has a certain degree of improvement, moral and ideological realm has been sublimated.

At the same time, under the diversified atmosphere, campus environment for college students can hard-working, brave and honest, modest and prudent, serious decisive qualities such as shape. Therefore, the university education has the significance which affects the life.

\section{The Importance of Ideological and Moral Education in Physical Education}

Physical education is an important part of college education, which has a comprehensive educational function for the development of students' moral character, intelligence and health. Compared with the mainstream curriculum, physical education has a special teaching method, form and place, so it has some advantages in other aspects.

\subsection{Favorable Conditions of Education}

For college education, interest is the first motivation for students to learn, only to make the students in the classroom on the desire for knowledge, teachers want to impart knowledge and ideas can be recognized and accepted by students. Therefore, college education is the process of students' independent learning, cramming before this and universities are essentially different[6].

Compared with other mainstream courses, the combination of Chinese and American sports teaching gives its unique charm. In the process of teaching, to stimulate students' interest in learning 
is particularly important, spirit, tactics and techniques of beauty can become a sport for students' attraction. In the mode of examination oriented education, students entering the University before the time of the outdoor exercise less and less awareness of sports is not enough. College education is a good opportunity to refresh the students' learning ideas. The relaxed and easy teaching content designed by the teacher is easy to stimulate the curiosity of the students, and the students' creativity can burst out in a relaxed atmosphere, which lays a solid foundation for ideological and moral education.

\subsection{Easy Way of Education}

The result of education is greatly influenced by the way of teaching. Because of the need for technical guidance, the students and students, teachers and students have a lot of physical contact, there is a close relationship between each other. The relaxed and dynamic teaching content of teachers' design, it is easy to narrow the distance between teachers and students, form a more harmonious classroom atmosphere. To carry out moral education in this course, students will listen to more positive and cheerful attitude, didactic education in the sports teaching mode of dull as ditch water, not too would have been their resistance. In this process, the development of a number of simple teaching games, but also can make the collective consciousness and team spirit of the concept of more effective communication to students. Students in the cooperation and competition to win a game, but also cannot to train and upgradea sense of unity and cooperation.

\subsection{Harmonious Education Atmosphere}

With ideological and moral education in the collective atmosphere, the students will be more participation and acceptance, the scope of its impact will be compared to a large degree of personal activities to expand. In the process of physical education for college students, the differences between individuals have different effects on the improvement of the basic quality of different students. The development of students' personality must be from the reality, in this process, students in the form of collective knowledge and skills to learn. This is not only the process of improving the quality of the body, but also the process of shaping the spirit of the world, is conducive to students to experience the sense of integration into the community and the sense of participation in social activities. Physical education itself has a relaxed learning atmosphere, is the ideological and moral education in the development of favorable conditions.

\subsection{Educational Effect Ideal}

The sports teaching will often carry out some fair competition and confrontation teaching practice, this competitive teaching method can help teachers to students' physical condition, tactical awareness and team spirit have mastered. At the same time, can effectively improve students' cooperation, the spirit of the students never yields in spite of reverses, positive, confident and brave good quality[7].In this process, between the teachers and the students of mutual cooperation and confrontation, failed to bear and the success of the share, make teachers and students across the barriers of age, has become a competitive game partner, naturally more students to the teacher trust. The ideological and moral education at this time is more convincing, don't need a textbook of preaching, game drops have significant influence on the shaping of the spiritual world of the students, the teacher's virtue is the best education itself, such moral education will achieve the best results. 


\section{How to Infiltrate Ideological and Moral Education in PE Teaching}

\subsection{Set Goals}

How will the ideological and moral education into daily physical education has very high requirements on the teaching content, must be clear objectives, detailed and reliable, easy to implement, must have specific plans for each class[8].For physical education teachers, scientific and detailed curriculum is helpful to the development of teaching work. At the same time, choose the specific content of the ideological and moral education, we must pay more attention to the content and the construction of socialist Chinese shall not violate this principle, should be conducive to college students' correct outlook on life, world outlook and values shaping.

\subsection{Select Material}

In the process of Ideological and moral education to students, to avoid the death of the dogma of teaching methods, teaching materials as far as possible and the combination of international hot spots, the theory and practice linked[9].For example, China now wants to express the people's living level, to the success of the Beijing Olympic Games as an example, to highlight its China excellent traditional culture show, in order to students with patriotism as the core of the national spirit of shaping. In addition, watching sports events is also a good way of teaching, athletes in the game is not afraid of hardship, not afraid of tired, the spirit of hard work for students have a good incentive. An important scene flag scene is students' patriotism burst, on students' self-esteem, for the spirit rises to a great extent.

\subsection{Follow the Law}

For college students, their physical and psychological development is not perfect, so the university education is an important way to improve their physical quality and form a correct outlook on life. Because of the difference of the growth environment and their own experience, different students have different ideological and moral standards. Therefore, in the process of education, in addition to the effective solution to the problem of the masses, the individual problems of the study should also pay attention to teachers[10].In the teaching arrangements, according to the difference between individuals, on the reasonable design of the learning strength, improve students' physical quality at the same time not to overwork, should pay attention to grasp the degree. Only in this way, the effect of Ideological and moral education in this process will not be affected, it can be carried out smoothly.

\subsection{Pay Attention to Teachers}

Education is not only with constraints on the restrictions and fetters of students, also have certain requirements on the quality of teachers. As the executor of education, the teachers' ability and spirit have a subtle influence on their students. Therefore, the teachers' education awareness and quality also need to be cultivated, which is the premise and key to improve the quality of students, has an important guiding significance. In addition, the implementation of the party's education policy is the basis for the implementation of the overall quality education for students.

\subsection{Pay Attention to Details}

In the process of physical education, the teacher's demonstration action is an important means for students to learn, and its vivid and intuitive help students to grasp the essentials of action. At the same time, the teaching of teachers to show the action, but also makes the confidence of the students to be inspired, the sense of competition between each other to a certain extent. The teacher's teaching action is skilled or not, it also helps to shape the image of the students in the 
minds of students, the effect of Ideological and moral education of students will be affected. In addition, the teacher also vivid language in the process of education can be to stimulate students' interest in learning, but also helps to form a good atmosphere in the classroom, these are to enhance the students to accept the favorable conditions of the ideological and moral education.

\section{Conclusion}

For the comprehensive development of college students, physical education has a positive role in promoting. Through the organic combination of cultural education, skills education and ideological and moral education, physical education can achieve the all-round development of people, and is helpful to the cultivation of high-quality talents. In the ideological and moral education penetration into the process in the teaching of physical education, must unremittingly long-term and systematic education, the teaching content is constantly enriching and improve the teaching method, in order to build college students correct world outlook, outlook on life and values. Based on the analysis of the importance of Ideological and moral education at the same time, the paper proposes the combination of physical education and the idea of this kind of concept, analyzes the advantage, and on how to implement the mutual penetration launched Lenovo in the hope to have some positive impacts on the ideological and moral education of PE in Japan.

\section{References}

[1] Xiong Wen, Zhang Jianyong.Multidimensional survey of moral education in school physical education[J]. Journal of Shanghai Physical Education Institute. 2006(05)

[2] Yang Changnan, Wang Enhui.On the characteristics of Ideological and moral education in Physical Education[J].Journal of HeFei University of Technology (SOCIAL SCIENCE EDITION). 2005(05)

[3] Li Chunlin, Ma Tingting, Lin Xiya.Research on the effective ways of College Students' Ideological and political education in the new period[J].School party building and Ideological Education. 2010(34)

[4] Chen Shuai.On the ideological and moral education in Physical Education in Colleges and Universities[J]. Journal of Guangdong University of Technology (SOCIAL SCIENCE EDITION). 2008(02)

[5] Liu Bin.On moral education in Physical Education[J].Heilongjiang Science and Technology Information. 2009(30)

[6] Chen Yunxi.Ideological and moral education in College Physical Education in twenty-first Century[J].Sports world (Academic Edition). 2009(05)

[7] Zhao Fang.On the cultivation of students' Ideological and moral character and will quality[J].New curriculum research (Basic Education). 2008(05)

[8] Tan ping, Li Gongzhen, Peng Xiaonian, Chen Jianjun.The study of Ideological and moral education in primary and secondary schools[J].Chinese School Physical Education. 2001(01).

[9] Li Ying.Analysis of the influence of physical education on students' personality development[J].Sports world (Academic Edition). 2008(03)

[10] Mao Zhenming, Lai Tiande.Interpretation of Chinese physical education curriculum and teaching reform[M]. Beijing Sport University press.2006 